Fisheries as assistant secretary, and in 1917-19 was deputy director-general of the Food Production Department. He was a member of the Royal Commission on Agriculture in India, which sat in 1926-28. $\mathrm{He}$ was the first recipient of the Gold Medal of the Royal Agricultural Society of England, awarded for services to agriculture.

\section{A Tribute to Sir John McFadyean}

IT was a happy thought that prompted some of his colleagues to obtain Sir John McFadyean's consent to allow them to design and edit the December (1937) number of the Journal of Comparative Pathology and Therapeutics as a jubilee number and Festschrift. This number forms the conclusion of the fiftieth volume of the journal, which was founded by Sir John McFadyean in 1888, and has since been edited by him almost entirely single-handed, and this unique occasion has been utilized to issue this number as a Festschrift in honour of Sir John's outstanding contributions to veterinary science during his long career. These have been mainly confined to problems concerning the control of tuberculosis, contagious abortion and glanders among farm animals, the etiology and occurrence of Johne's disease in Great Britain, and the discovery that the virus of horse sickness is a filterable one. The esteem in which Sir John is held is manifest from the contributions contained in this number, which come from all parts of the world. Appreciations of the man and his work are contributed by many, including Sir John Kelland of the Ministry of Agriculture and Fisheries; Sir Robert Muir ; Sir John Ledingham; Prof. von Ostertag, Tübingen; Dr. Schmaltz, Berlin ; Prof. Leclainche, Paris; Dr. Mohler, United States; and Dr. Hilton, Canada. Several excellent portraits of Sir John are reproduced.

\section{Dr. H. J. Gough, M.B.E., F.R.S.}

DR. H. J. GoUGH, superintendent of the Engineering Department of the National Physical Laboratory, has been appointed to the new post of director of scientific research at the War Office. Dr. Gough will be directly responsible to the director-general of munitions production for the general direction and organization of research work for War Office purposes; for advising as to the programme of research work to be undertaken and as to proposals for specific investiga. tions; and for the efficiency of the organization for research and experimental purposes of the various research organizations under the War Office. $\mathrm{He}$ will represent that Department on the various interdepartmental research organizations.

\section{Tercentenary of Two French Botanists}

The year 1638 saw the birth of two notable French botanists, Guy-Crescent Fagon, who was born in Paris on May 11, 1638, and Pierre Magnol, who was born at Montpellier on June 8, 1638. Both were physicians, both were connected with botanical gardens and both were members of the Paris Academy of Sciences. Fagon was a nephew of Guy de la Brosse (died 164l) who first suggested and eventually, in 1626, laid out the "Jardin Royal de herbes médicinales" in Paris, the site of which was a piece of waste ground where the refuse of centuries had collected. It is now the Jardin des Plantes. After taking his degree in medicine in 1664, Fagon offered to procure plants for the garden, and through Antoine Vallot (1594-1671) the superintendent, who was also physician to the King, was appointed to travel in the Alps, Pyrenees, Auvergne and other parts. $\mathrm{He}$ afterwards became professor of botany and chemistry in the garden and in 1698 was made director. It was through him that two famous botanists, Joseph Tournefort (1661-1708) and Charles Plumier (16461704) were sent on collecting expeditions, one to the Levant and the other to America. He wrote on tobacco, cinchona and other matters, and held high office as a doctor. He died in Paris on March 11, 1718. Magnol was associated with Montpellier all his life. He took his degree there, assisted the professor of botany, in 1694 was given the chair of medicine and three years later was made director of the botanic garden, which had been founded about 1558. His writings referred mainly to the plants which grew in the neighbourhood of his native city. He died on May 21, 1715, leaving a son, Antoine. who followed in his footsteps. The genus Magnolia was named after him, by his countryman Plumier.

\section{International Ornithological Congress}

THE ninth International Ornithological Congress was held in Rouen during the second week in May under the presidency of Prof. A. Ghigi, rector of the University of Bologna, with M. Jean Delacour as secretary. Among the papers contributed which attracted most interest was that on his recent discovery of the Congo peacock (Afropavo) by Dr. J. Chapin, followed by a report on the anatomy of the bird by Mr. Percy R. Lowe. A large number of films of high merit were displayed by ormithologists of various nationalities, which showed how greatly Nature photography has advanced during recent years. Particular mention must be made of Prof. A. Allen's sound film, partly in colour, of rare and disappearing American birds and of Captain C. W. R. Knight's excerpts of the film he made when leading the National Geographic Society's 1937-38 expedition to South Africa, in which he showed three birds never filmed before-the hammerhead stork, crowned hawk eagle and secretary bird. It was agreed that the tenth International Congress should be held in America in 1942, and Dr. A. Wetmore of Washington was elected president.

\section{International Committee for Bird Preservation}

THE meetings of the International Committee for Bird Preservation, which were held in Rouen immediately preceding the Ornithological Congress, were attended by the official delegates of the national sections of fourteen different countries. The main subjects of discussion were the status of the Anatidæ throughout the world and the protection of the quail; a number of reports on progress in bird preservation in various countries were contributed. The destric. tion of sea-birds by waste oil was also discussed and, on the proposal of Prof. Einar Lönnberg of Sweden, a sub-committee was appointed to expedite means 